\title{
Cikkismertetés: Hasznos a jó szomszédi viszony?
}

\author{
Article review: Is it useful to have a good relationship with the neighbours?
}

Ismertető: $\quad$ Prievara Dóra Katalin $₫$

Szegedi Tudományegyetem, Juhász Gyula Pedagógusképző Kar, Alkalmazott Egészségtudományi és Egészségfejlesztési Intézet

Ismertetett cikk: Zhang S, Xiang W. Income gradient in health-related quality of life - the role of social networking time. International Journal for Equity in Health. 2019;18(44):1-10. doi: 10.1186/s12939-019-0942-1

Beküldve: $\quad$ 2019. 08.14.

doi: $\quad$ 10.24365/ef.v60i5.507

Kulcsszavak: egészséggel összefüggő életminőség; jövedelem; grádiens; szociális hálózatban töltött idő

Keywords: health-related quality of life; income; gradient; social networking time

Számos kutatás vizsgálta már az egészség és a társadalomban betöltött hely közötti kapcsolatot, melyek alapján ismert, hogy a kedvezőtlenebb társadalmi helyzetű emberek általában rosszabb egészségi állapottal rendelkeznek, magasabb köreikben a különféle betegségek megjelenésének a kockázata és a várható élettartamuk alacsonyabb, mint a magasabb társadalmi státuszú személyeké. $\mathrm{Az}$ egészség-egyenlőtlenségek csökkentésére irányuló erőfeszítések ellenére azonban az egészség területén az osztályok közötti különbségek tovább szélesednek.

A tanulmány célkitǔzése a jövedelem és az egészség kapcsolatának vizsgálata volt, illetve annak elemzése, hogy milyen moderáló erővel bír minderre a szociális hálózat egy speciális altípusa, a szomszédsági kapcsolatok.

A kutatók az „Általános Társadalmi Felmérés” (General Social Survey, GSS) adatait használták, amely felmérés az amerikai felnőttekről gyújt adatot 1972 óta azzal a céllal, hogy a társadalom szerkezetét és fejlődését vizsgálja. Az egészséggel összefüggő életminőséget az „Egészségben Eltöltött Napok Felmérés” (Healthy Days Measures, HDM) kérdéseire adott válaszok segítségével állapították meg. Ez a felmérés az elmúlt 30 napra vonatkozóan tartalmaz tételeket az általános, fizikai és mentális egészségre vonatkozóan. Ezáltal a megkérdezettek szubjektív benyomása is rögzíthető arra vonatkozóan, hogy mely egészségi probléma befolyásolja a mindennapjaikat.

Jelen cikkhez az adatok az Amerikai Egyesült Államokban végzett 2002-es, 2006-os, 2010-es és 2014-es adatgyűjtésekből származnak. Az elemzésben összesen 3330 fő vett részt, akik a GSS és a HDM felméréseket is kitöltötték mind a négy alkalommal. Ezen adatokon felül az elemzésbe bevonták a családi jövedelmet és a szociális hálót is. Ez utóbbi a környékbeliek társaságában eltöltött alkalmakat jelölte, ami a résztvevő́k esetében átlagosan havi néhány estét jelentett. A vizsgálatban kimondottan a szomszédokkal eltöltött idő számított, nem pedig a barátokkal, családdal való közös program.

Az adatok elemzése alapján megállapítható, hogy az egészséggel összefüggő életminőség pozitív korrelációt mutatott a családi jövedelemmel: a korábbi tanulmányoknak megfelelően a magasabb jövedelem magasabb életminőséggel járt együtt. Továbbá, a jövedelem negatív korrelációt mutatott a rosszabb egészségi állapotban töltött napok számával, míg az egészség általános értékelésével pozitív kapcsolatot, jól jelezve a jövedelem szerepét a szubjektív 
életminőség megítélésében. A jobb anyagi háttér az egészség több területén is előnyöket jelent, például az egészséggel kapcsolatos szolgáltatások, erőforrások elérésében, a minőségi táplálkozás kialakításában.

A szomszédokkal közösen töltött szabadidő vizsgálata során a kutatók azt az összefüggést találták, hogy az alacsonyabb jövedelemmel rendelkező egyének hajlamosabbak voltak több időt tölteni a szomszédjaik körében, mint a magasabb jövedelemmel rendelkező személyek. A szomszédjaikkal gyakrabban társas összejöveteleket szervező válaszadók ugyanakkor szegényesebb egészséggel összefüggő életminőségről számoltak be, főként a mentális egészség terén (stressz, depresszió), feltételezhetően a relatív depriváció érzete miatt. Azaz, a jövedelmek okozta különbségek nemcsak az életminőség megítélésében jelentek meg, hanem a szabadidő eltöltésére is kihatottak, ugyanis a magasabb jövedelemmel rendelkező személyek kevésbé keresik szomszédjaik társaságát.

\section{TANULSÁGOK A HAZAI SZAKEMBEREK SZÁMÁRA}

A cikk felhívja a figyelmet arra, hogy a család jövedelme szerepet játszik nemcsak az egészséggel összefüggő életminőség szubjektív megítélésében, hanem a szociális kapcsolatokban is, ahol újrateremtődnek a különbségek: a magasabb jövedelemmel rendelkező személyek ugyanis kevesebb időt fordítottak a szomszédjaikkal való szocializációra. Összességében a kutatók rámutatnak egy napjainkban kissé háttérbe szorult erőforrás, a szomszédság fontosságára. A valódi emberi kapcsolatok a szűkösebb anyagi lehetőségek esetén kompenzálásként instrumentális segítséget, szociális erőforrást és társas támogatást nyújthatnak. 